\title{
Morphological and molecular approaches reveal highly stratified protist communities along Baltic Sea pelagic redox gradients
}

\author{
Felix Weber $^{1}$, Ruth Anderson ${ }^{1}$, Wilhelm Foissner ${ }^{2}$, Alexander P. Mylnikov ${ }^{3}$, \\ Klaus Jürgens ${ }^{1, *}$ \\ ${ }^{1}$ Leibniz Institute for Baltic Sea Research Warnemünde, Department of Biological Oceanography, Seestrasse 15, \\ 18119 Rostock, Germany \\ ${ }^{2}$ University of Salzburg, Department of Organismic Biology, Hellbrunnerstrasse 34, 5020 Salzburg, Austria \\ ${ }^{3}$ Institute of the Biology of Inland Waters, Russian Academy of Sciences, Yaroslavskaya Obl., Borok, Russia
}

\begin{abstract}
The deep basins of the central Baltic Sea are characterized by anoxic and sulfidic bottom water and steep vertical pelagic redox gradients. The highly active prokaryotic assemblages of this and other redox transition zones have been intensely studied, while knowledge on the protistan communities remains fragmentary. Thus, we conducted a multi-annual microscopybased study, combined in one year with 18S rRNA gene and transcript-based DGGE fingerprints to identify the dominant protist taxa and to assess their vertical distribution. Both approaches, applied in high vertical resolution, demonstrated strong stratifications of the protist community composition along the redox gradient. The suboxic zone was dominated by dinoflagellates and oligotrichous ciliates related to Strombidium, whereas the interface and upper sulfidic zone were dominated by ciliates of the genera Mesodinium and Metacystis. Several flagellate taxa within the jakobids, euglenozoans and choanoflagellates occurred exclusively in sulfidic water. Our morphological approach indicates that the pelagic redoxclines of the central Baltic Sea are inhabited by a stable and characteristic protist community. Incongruously, certain taxa (e.g. Mesodinium and Metacystis sp.) which remained undetected by the molecular fingerprinting technique could be identified and enumerated by microscopic observations, whereas small and virtually amorphous protists (especially flagellates) were detected only by sequencing DGGE bands. Fine-scaled assessment of dominant protists in distinct redox strata is a crucial step in understanding their impact and interactions with the prokaryotic world and the biogeochemical processes they mediate in these zones.
\end{abstract}

KEY WORDS: Protists - Ciliates · Flagellates - Metacystis · 18S rRNA · Stratification - Redox gradient $\cdot$ Baltic Sea

\section{INTRODUCTION}

Up to $7 \%$ of the modern ocean is considered to be devoid of oxygen, including upwelling regions on the western continental shelves and stratified marginal seas (Baltic Sea, Black Sea) as prominent examples (Wright et al. 2012). Oxygen depleted environments, and oxic-anoxic transition zones (redoxclines) in par- ticular, are known as sites of high redox-driven microbial activity, with impacts on the carbon, nitrogen and sulfur cycling, trace gas production and organic matter fluxes (Ulloa et al. 2012, Wright et al. 2012). Recent studies revealed novel insights into the taxonomic and functional diversity of prokaryotes in these systems, with the identification of many novel bacterial and archaeal lineages together with new 
aspects of their metabolic activity and their role in the biogeochemical cycles (Ulloa et al. 2012, Wright et al. 2012).

In contrast, our knowledge of protistan communities in oxygen depleted systems is lagging tremendously behind, even though the first record of protists from anoxic sites dates back more than a hundred years (Lauterborn 1901). Protists play a fundamental role in all aquatic environments as grazers that control both the standing stocks and community structure of prokaryal assemblages and the pico- and nanoplankton (Sherr \& Sherr 2002, Jürgens \& Massana 2008). Protists in anoxic systems also act as hosts for numerous symbiotic archaeal and bacterial cells (Fenchel \& Finlay 1995, Bernhard et al. 2000, Orsi et al. 2012a). Therefore, both as predators and as symbiotic hosts, protists can significantly influence ecological processes, such as the fate of prokaryal matter production and the metabolic potential of microbial assemblages.

Morphological characterizations of protists in hypoxic water layers of marine and freshwater systems have shown highly stratified community structures and enhanced protist abundances at oxic-anoxic interfaces (Fenchel et al. 1990, Zubkov et al. 1992, Massana \& Pedrós-Alió 1994, Guhl et al. 1996, Finlay \& Esteban 1998). However, most of those studies focused on protistan functional guilds or protists with conspicuous morphological features, thus providing only little taxonomical resolution especially for smaller eukaryotes. Overall, this led to the assumption that anoxic waters are rather poor in species richness (Fenchel \& Finlay 1990a, 1995).

18S rRNA sequencing approaches changed this view, uncovering an astonishingly high diversity and multiple novel lineages of microbial eukaryotes in the pelagial and sediments of anoxic and oxygen depleted environments (e.g. Dawson \& Pace 2002, Edgcomb et al. 2002, Stoeck \& Epstein 2003, Stoeck et al. 2003, Zuendorf et al. 2006, Edgcomb et al. 2011a). Furthermore, molecular studies provided the first hints of a fine-scale architecture and seasonal variations in the protistan community structure along marine redox gradients (Behnke et al. 2006, 2010, Orsi et al. 2011, Wylezich \& Jürgens 2011). However, with a few exceptions (Coolen \& Shtereva 2009, Behnke et al. 2010, Orsi et al. 2011, 2012b), 18S rRNA-based approaches were generally applied as snapshot surveys covering only very few samples within the water column and with low temporal resolution. Additionally, for various reasons, 18S rRNA-based approaches are only marginally suitable for quantitative assessments of a taxon's cellular abundance or biomass contribution to the protistan assemblage (Caron 2009). Consequently, the spatio-temporal changes of protistan communities in such systems remain mostly unresolved by molecular techniques, which have been seldom accompanied by parallel morphology-based approaches (Edgcomb et al. 2011b,c, Orsi et al. 2012a,c, Wylezich et al. 2012).

The brackish Baltic Sea, with its steep pelagic redox gradients, represents an ideal model system to study microbial communities in response to oxygen depletion and sulfide accumulation in deeper waters. In contrast to numerous detailed studies on the prokaryotic assemblages (e.g. Labrenz et al. 2007, 2010, Jost et al. 2008, Grote et al. 2012), protist related studies of Baltic Sea redoxclines are limited to a few microscopy-based approaches (Setälä 1991, Detmer et al. 1993) and one single 18S rRNA-based diversity study, covering 2 water depths of the Gotland Deep (Stock et al. 2009). Two recent studies, which also provide data for different protist functional groups, focused on the role of protist grazing and viral lysis as prokaryotic mortality factors in the redox gradient (Anderson et al. 2012, 2013). Here, we used morphological and molecular techniques to describe the stable and fine-scaled distribution patterns of protists and to identify dominant taxa which are indigenous to distinct redox zones in the Baltic Sea.

\section{MATERIALS AND METHODS}

\section{Study sites and sampling}

Water samples were collected in the central Baltic Sea at Gotland Deep (Stn 271: $57^{\circ} 19.2^{\prime} \mathrm{N}, 20^{\circ} 03^{\prime} \mathrm{E}$ ) and Landsort Deep (Stn 284: $58^{\circ} 35.0^{\prime} \mathrm{N}, 18^{\circ} 14.0^{\prime} \mathrm{E}$ ) onboard the RV 'Alkor' in May 2005, the RV 'Professor Albrecht Penck' in July 2007 and the RV 'Poseidon' in August 2008 (Table 1). Sampling was performed with a CTD rosette (SeaBird Electronics) equipped with 51 Free-Flow Bottles (Hydrobios). Water masses were sampled at 10 to $50 \mathrm{~m}$ and 2 to $5 \mathrm{~m}$ depth intervals to obtain whole water column profiles (Gotland Deep 2007) and high resolution profiles of the oxic-anoxic transition zone (Gotland Deep 2005, 2007, 2008 and Landsort Deep 2008). In all cases, inorganic nutrients, oxygen and hydrogen sulfide were measured immediately onboard according to standard methods (Grasshoff et al. 1983). An overview on the different approaches used in the different years is given in Table 1 . 
Table 1. Sampling effort for different analyses done during 3 cruises in 2005, 2007 and 2008 at Gotland Deep and Landsort Deep. The number of samples for each analysis is given. Redox: high resolution redoxcline profile, Whole: whole water column profile

\begin{tabular}{|c|c|c|c|c|c|c|}
\hline & \multirow{2}{*}{\multicolumn{2}{|c|}{2005 May }} & \multirow{2}{*}{\multicolumn{2}{|c|}{$\begin{array}{l}\text { Gotland Deep } \\
\quad 2007 \text { July }\end{array}$}} & \multirow{4}{*}{$\begin{array}{l}2008 \text { August } \\
\text { Redox } \\
114-136 \mathrm{~m}\end{array}$} & \multirow{4}{*}{$\begin{array}{c}\text { Landsort Deep } \\
2008 \text { August } \\
\text { Redox } \\
80-115 \mathrm{~m}\end{array}$} \\
\hline & & & & & & \\
\hline & Redox & Redox & Whole & $\begin{array}{l}\text { Redox } \\
119-143\end{array}$ & & \\
\hline & $180-220 \mathrm{~m}$ & $181-221 \mathrm{~m}$ & $6-232 \mathrm{~m}$ & 119-143 m & & \\
\hline Physico-chemical parameters & 12 & 11 & 13 & 13 & 12 & 13 \\
\hline \multicolumn{7}{|l|}{ Determination of cell numbers } \\
\hline Prokaryotes & 12 & 11 & 13 & 13 & 12 & 13 \\
\hline $\mathrm{HNF}$ & & & 13 & 13 & 12 & 13 \\
\hline Dinoflagellates & & & 13 & 13 & 12 & 13 \\
\hline Ciliates (incl. morphotypes) & 12 & 11 & 13 & 13 & 12 & 13 \\
\hline \multicolumn{7}{|l|}{ Taxonomic identification } \\
\hline Ciliates & 2 & 2 & & & & \\
\hline \multicolumn{7}{|l|}{ Molecular analysis } \\
\hline DGGE fingerprint & & & 13 & 13 & & \\
\hline
\end{tabular}

\section{Determination of microbial cell abundance and biomass}

To determine prokaryotic cell abundance, samples $(4 \mathrm{ml})$ were immediately fixed with paraformaldehyde and glutaraldehyde (final conc. $1 \%$ and $0.05 \%$, respectively), deep-frozen in liquid nitrogen and stored at $-80^{\circ} \mathrm{C}$ until processing. Upon thawing, prokaryotic cell counts were determined with a FACScalibur (Becton \& Dickinson) flow cytometer following a previously described protocol (Gasol \& del Giorgio 2000).

To assess the abundance of heterotrophic nanoflagellates (HNF), samples $(100 \mathrm{ml})$ were fixed immediately after retrieval with glutaraldehyde $(1.25 \%$ final conc. in 2005 and $0.5 \%$ final conc. in 2007) or with particle free formaldehyde ( $1 \%$ final conc. in 2008) at $4^{\circ} \mathrm{C}$ for 2 to $24 \mathrm{~h}$. Aliquots of $40 \mathrm{ml}$ were then vacuum filtered (100 mbar) onto black polycarbonate filters (Nucleopore; $0.8 \mu \mathrm{m}$ pore-size; Whatman). In 2007, filters were stained onboard with DAPI (0.01 $\mathrm{mg} \mathrm{ml}^{-1}$ final conc.) prior to storage at $-20^{\circ} \mathrm{C}_{i}$ in 2005 and 2008 , filters were first stored at $-20^{\circ} \mathrm{C}$ and stained with DAPI upon thawing (tests were conducted to ensure this did not affect cell counts, F. Weber unpubl. data). Observation and counting of a minimum of 100 HNF cells per sample was performed at a magnification of $630 \times$ and an excitation wavelength of $360 \mathrm{~nm}$ (filter set 02, Carl Zeiss Microscopy) under a Zeiss Axioskop 2 mot plus epifluorescence microscope (Carl Zeiss Microscopy).

Enumeration of ciliates and dinoflagellates was accomplished following the Utermöhl technique (Utermöhl 1958) with samples $(200 \mathrm{ml})$ previously fixed with Lugol's solution (1\% final concentration) (Willen 1962). Samples were processed as described in Ander- son et al. (2012) and cells were enumerated by screening between 10 diagonal stripes (representing one third of the total area) and the whole counting chamber. Ciliates were classified as morphotypes of the genera Metacystis, Mesodinium, Strombidium (in 2005, 2007 and 2008), Metopus, Tintinnopsis, Spathidium and Uronema (in 2005) (Foissner et al. 1999).

Protist biomass estimates were derived from individual cell volume calculations of distinguished morphotypes and size classes using approximate geometric forms. The carbon content per cell was determined by means of specific cell volume to biomass conversion factors from the literature $(220 \mathrm{fg} \mathrm{C}$ $\mu^{-3}$ for HNF, Børsheim \& Bratbak 1987; 125 fg C $\mu^{-3}$ for dinoflagellates, Pelegri et al. 1999 and $190 \mathrm{fg}$ $\mathrm{C} \mu \mathrm{m}^{-3}$ for ciliates, Putt \& Stoecker 1989) and was multiplied by the cell abundance to obtain the total biomass for each protist group at the sampled depths. It should be noted that the use of different fixation methods might have affected the identification and enumeration of some protists (Sherr \& Sherr 1993).

\section{Taxonomic identification of novel ciliates}

A more comprehensive taxonomic identification of dominant ciliates from the oxic- anoxic interface of the Gotland Deep was performed in 2005 (Foissner et al. 1999 and literature cited therein). Live ciliates were concentrated by gravity filtration of 40 to $50 \mathrm{l}$ of seawater through a submerged $10 \mu \mathrm{m}$ mesh size plankton net, thereby largely reducing air contact. Onboard, the concentrated material was stored at $4^{\circ} \mathrm{C}$ and then sent on ice to the laboratory in Salzburg. There, samples were checked for the species present, and those which were likely unde- 
scribed were studied in vivo and by various silver impregnation methods as described in Foissner (1991).

\section{Detection of potential symbiotic bacteria associated with redoxcline ciliates}

Water samples from the oxic-anoxic interface $(129 \mathrm{~m})$ in 2007 were fixed with $0.2 \mu \mathrm{m}$ filtered formaldehyde (final conc. $2 \%$ ) and filtered on $0.8 \mu \mathrm{m}$ pore diameter polycarbonate filters. Fluorescence in situ hybridization (FISH) was accomplished as described in Pernthaler et al. (2001), with $35 \%$ of deionized formamide in the hybridization buffer. Either a mixture of eubacterial probes (EUB338 I-III; Daims et al. 1999) or a probe specific for Gammaproteobacteria (GAM42a + non labelled competitor probe Bet42a; Manz et al. 1992) was used. DAPI-stained ciliates were inspected for hybridized bacterial cells within the cytoplasm or the cell surface. Among the ciliates that were associated with bacteria, several were unidentified, whereas many belonged to the genus Metacystis, according to the prominent morphology.

\section{Nucleic acids extraction and ribosomal complementary DNA (rcDNA) synthesis}

Samples for nucleic acids extraction were taken parallel to the samples for microscopical cell counts in the profile from Gotland Deep in 2007. Microbial biomass was collected on $0.2 \mu \mathrm{m}$ pore size polycarbonate filters (Durapore, Millipore), shock frozen in liquid nitrogen and stored at $-80^{\circ} \mathrm{C}$ until nucleic acid extraction was performed. A combination of mechanical and chemical procedures was used in order to simultaneously extract RNA and DNA as described by Weinbauer et al. (2002).

The separated DNA and RNA extracts were washed twice with $70 \%$ ice cold ethanol and dissolved in nuclease free water. Residual environmental DNA was eliminated in RNA extracts by DNase I digestion (DNA-free Kit, Ambion) for $30 \mathrm{~min}$ at $37^{\circ} \mathrm{C}$. An aliquot of both nucleic acids was quality-checked and quantified using a NanoDrop ND-1000 UV/Vis spectrophotometer (NanoDrop, Thermo Fisher Scientific). Enzymatic degradation of RNA was prevented by treating each RNA extract with $0.9 \mu \mathrm{l}$ RNase inhibitor (Peqlab) per $20 \mu \mathrm{l}$ of RNA sample. Complete removal of the DNA in each of the RNA extracts was verified by PCR, as described in the next section, using the RNA extracts as template. To gen- erate cDNA, $\sim 200 \mathrm{ng}$ of template RNA was reverse transcribed at $42^{\circ} \mathrm{C}$ using the iScript Select cDNA synthesis kit (Bio-Rad) following the manufacturer's recommendations. In addition to the random primer provided with the kit, the eukaryote-specific primer Euk B (Medlin et al. 1988) was used. In each reverse transcription reaction, some of the RNA samples were not supplemented with reverse transcriptase as an additional control for DNA contamination.

\section{Denaturing gradient gel electrophoresis (DGGE)}

18S rRNA fragments ( 560 bp length) were amplified by PCR using both DNA and cDNA as template with the eukaryote specific primers EukA and Euk516r-GC (Medlin et al. 1988, Amann et al. 1990). The PCR mixture $(25 \mu \mathrm{l})$ was composed of $200 \mu \mathrm{M}$ of each deoxynucleoside triphosphate, $0.47 \mathrm{mM}$ of each primer, $1.25 \mathrm{U}$ of Taq DNA polymerase (Eppendorf) and the $\mathrm{Mg}^{2+}$ self-adjusting PCR buffer supplied with the enzyme (Taq Buffer advanced, Eppendorf). PCR was started with an initial denaturation at $94^{\circ} \mathrm{C}$ for 2 min, followed by 34 cycles of $30 \mathrm{~s}$ at $94^{\circ} \mathrm{C}, 45 \mathrm{~s}$ at $56^{\circ} \mathrm{C}$ and $2 \mathrm{~min}$ at $72^{\circ} \mathrm{C}$. The final extension step was done at $72^{\circ} \mathrm{C}$ for $6 \mathrm{~min}$

DGGE was performed as described in Weber et al. (2012) with denaturing conditions ranging from 40 to $55 \%$. For a better comparison of band positions in different gel runs, an environmental DGGE standard with defined bands (loaded to middle and outer lanes) was developed using samples from the same sampling campaign. Gel images were subjected to cluster analysis with the software GelCompare II (Applied Maths). Densiometric curves of each lane were used to calculate dendrograms after Pearson correlation under the UPGMA model. Additionally, cophenetic correlation coefficients were estimated for each node of the dendrogram.

Across lanes, DGGE bands were assigned banding positions, excised from the gel and eluted overnight at $4^{\circ} \mathrm{C}$ in $50 \mu$ of nuclease free water before they were stored at $-20^{\circ} \mathrm{C}$. For reamplification of bands, $1 \mu \mathrm{l}$ of a 1:10 000 dilution of the eluate served as template in a PCR with the previously described conditions. Subsequently, all reamplicons were verified to derive from a single DGGE band by subjecting them to additional DGGE runs. The final reamplification was done with the reverse primer lacking the GC clamp. PCR products were purified with the NucleoSpin ${ }^{\circledR}$ Extract II kit (Macherey-Nagel). The sequencing reactions were carried out with the primer EukA by the sequencing service QIAGEN. Bands were 
excised and sequenced from the same band position in several lanes. All bands assigned to a position were quantified by their relative band intensity, translated into diameter values and were plotted as bubbles according to their presence in the depth profiles.

\section{Phylogenetic analysis}

Chromatograms supplied with each sequence were reviewed in SeqManII (DNAStar) and ends containing unreliable trace data peaks were trimmed manually. Sequences were submitted to KeyDNATools (www.keydnatools.com) and BLAST (Altschul et al. 1997) for chimera detection and taxonomic affiliation. Representative 18S rRNA sequences of a single operational taxonomic unit (OTU) based on $99 \%$ similarity were called by creating a distance matrix and clustering of sequences according to the average-neighbor method in Mothur (Schloss et al. 2009) and were deposited in GenBank under accession numbers KF373741 to KF373752.

Multiple alignments were done using MAFFT version 6 (Katoh et al. 2002) and were inspected and manually refined in BioEdit (Hall 1999). Bayesian and maximum likelihood phylogenetic trees with 57 complete and partial 18S rRNA sequences were calculated using MrBayes version 3.2.1 (Ronquist et al. 2012) and RAxML version 7.0.4 (Stamatakis 2006), launched via the web-based computational resource Bioportal of the University of Oslo (Kumar et al. 2009). Trees generated with both methods were fairly similar in topology (overall topological score $=94.5 \%$ ) as calculated from Compare2Trees (Nye et al. 2006), and, therefore, only the Bayesian tree is shown. The Bayesian likelihood parameters were set to the substitution model GTR. Rate variation across sites was modeled using a gamma-shaped rate variation with a proportion of invariable sites. Rate variation across the tree was allowed under the covarion-like model. Monte Carlo Markov chain (MCMC) search was run with 4 chains for 1000000 generations, with trees being sampled every 100 generations. Bayesian posterior probabilities were calculated under the MCMC method. The first $25 \%$ of sampled trees were considered 'burn-in' trees and were discarded prior to tree reconstruction. The maximum likelihood phylogenetic tree and bootstrap analysis in RAxML were done in 1000 replicates on random starting trees under the evolutionary model GTRGAMMA. A consensus tree, displaying the bootstrap values, was computed in MrBayes and respective values were transferred into the Bayesian topology tree.

\section{RESULTS}

\section{Physico-chemical characteristics of the central Baltic Sea water column}

During our observation period at Gotland Deep in 2007, 2008 and Landsort Deep in 2008, we found a characteristic water column stratification for the central Baltic Sea (Jost et al. 2008, Anderson et al. 2012), as exemplified for the Gotland Deep in 2007 in Fig. 1. The euphotic zone extended down to $16 \mathrm{~m}$, determined as the depth where irradiance represented $1 \%$ of subsurface photosynthetically active radiation. The water column was characterized by a thermocline and a deeper halocline. Between these 2, the cold intermediate water layer was situated with higher oxygen concentrations than surface waters. Below the halocline, oxygen declined until its complete depletion at the redoxcline (transition zone between oxygenated and sulfidic waters). The chemocline demarcated the beginning of the sulfidic part of the water column, which was characterized by steadily increasing $\mathrm{H}_{2} \mathrm{~S}$ content towards the seafloor (Fig. 1B).

\section{Microbial abundance and protistan community structure along the redox gradient based on microscopical analysis}

In the water column, the abundance of all microbial cells (prokaryotes, HNF, dinoflagellates and ciliates) was highest in the surface zone; declined drastically with decreasing oxygen tension and showed a second, smaller peak near the chemocline (Fig. 1B,C). Prokaryote abundance (including both Bacteria and Archaea) at the chemocline was one fourth of the concentration detected at the surface, while HNF, dinoflagellates and ciliates accounted for 6,13 and $20 \%$ of their respective abundances in surface waters. Biomass estimates for different functional groups of protists showed a dominance of ciliates at the oxic-anoxic interface (87 to $97 \%$ in all profiles investigated, Fig. 1D). The sulfidic part of the water column was characterized by very low protist cell numbers, while the abundance of prokaryotes remained high and even slightly increased towards the seafloor (Fig. 1B).

High resolution cell counts along the redox zones of Landsort and Gotland Deep from 2007 and 2008, plotted against oxygen concentrations, exhibited a consistent distribution pattern of prokaryotes, HNF, dinoflagellates and ciliates (Fig. 2). Highest prokaryotic cell numbers were detected directly at or around the oxicanoxic interface (dashed line). At sulfidic depths, cell 


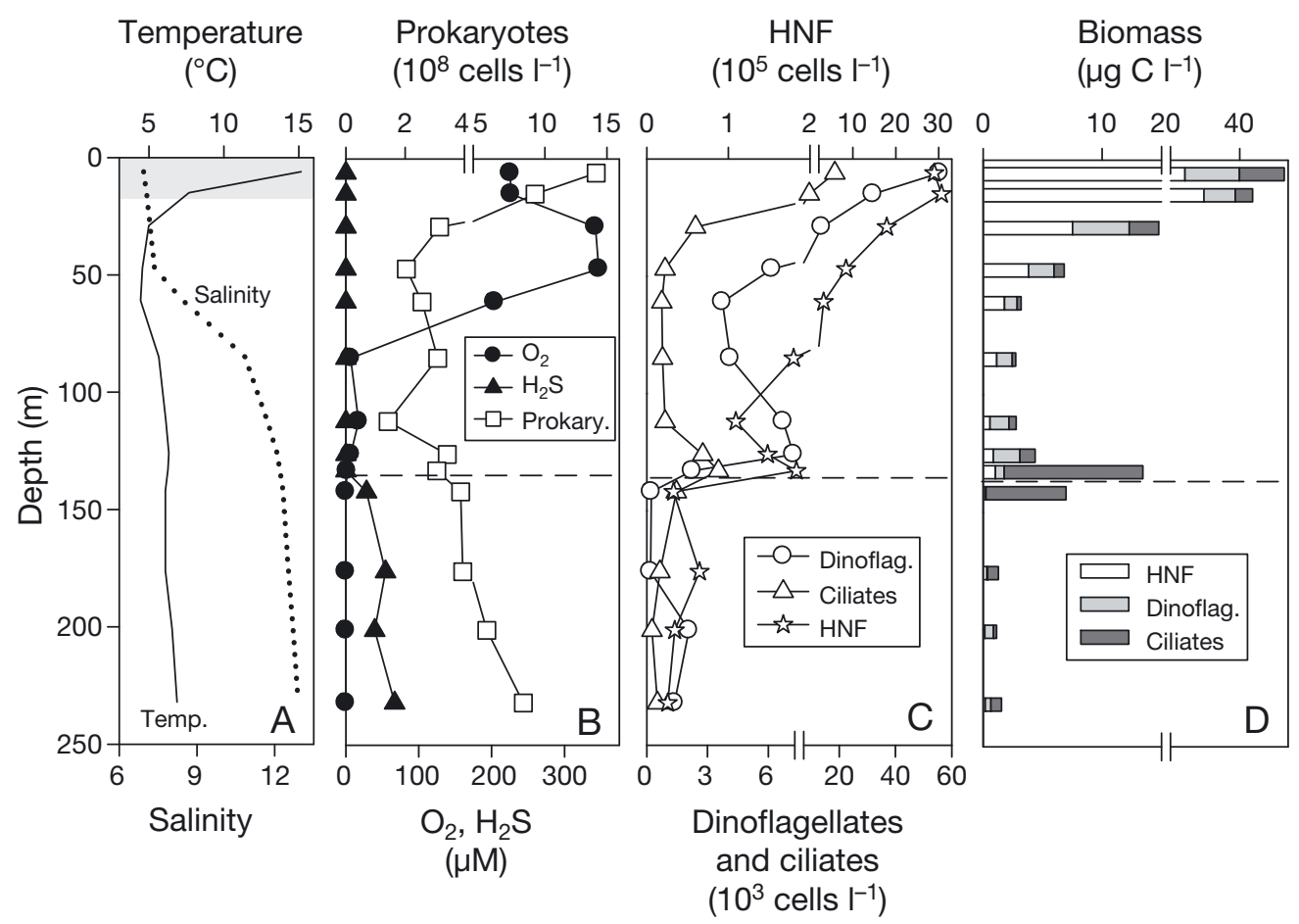

Fig. 1. Whole water column profile at Gotland Deep in July 2007. (A) Temperature and salinity profile. Changes with depth in (B) oxygen, hydrogen sulfide and prokaryote concentrations, and (C) the abundance of the 3 protist functional groups (heterotrophic nanoflagellates (HNF), dinoflagellates and ciliates). (D) Vertical biomass distribution of HNF, dinoflagellates and ciliates. The shaded area in (A) is the extension of the euphotic zone (defined as $1 \%$ of subsurface photosynthetically active radiation). The horizontal dotted line indicates the oxic-anoxic interface

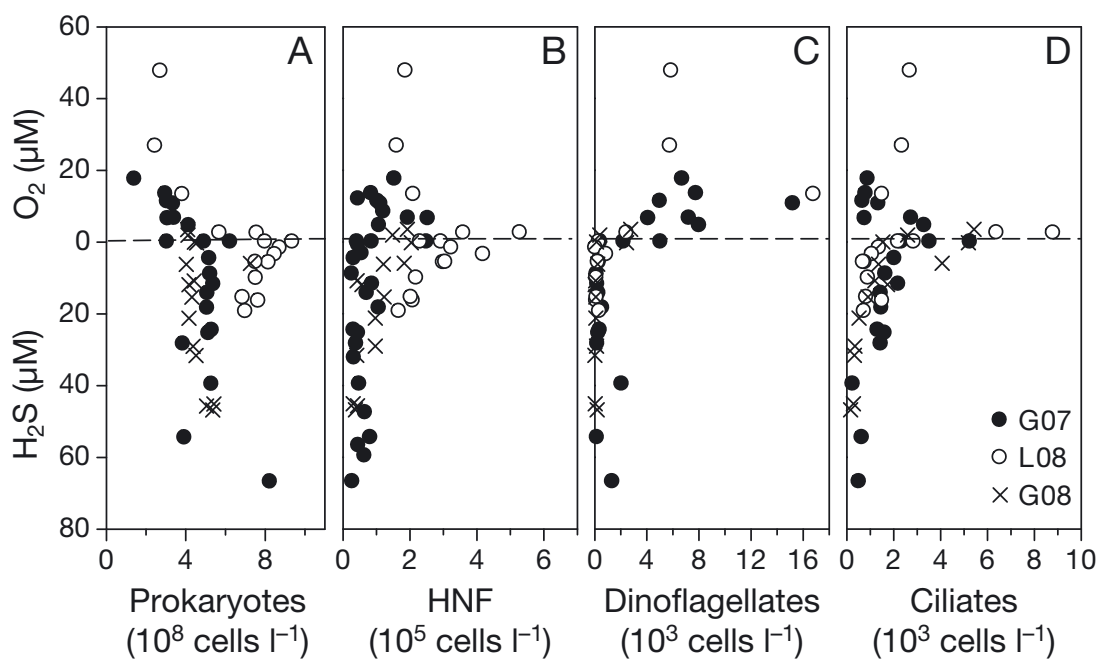

Fig. 2 Changes in the abundance of (A) prokaryotes, (B) heterotrophic nanoflagellates (HNF), (C) dinoflagellates and (D) ciliates along the oxygen gradients of the Gotland Deep in July 2007 (G07), August 2008 (G08) and Landsort Deep in August 2008 (L08). The $y$-axis is split into values for oxygen and hydrogen sulfide concentration, while a value of 0 indicates that both were below detection (detection limit: $2 \mu \mathrm{M}$ and $0.2 \mu \mathrm{M}$, respectively). Dashed line represents the oxic-anoxic interface

numbers declined slightly but still exceeded those found in the suboxic zone. Overall, higher prokaryotic cell counts were obtained in Landsort Deep than in Gotland Deep, with respective maximal abundances of $9.4 \times 10^{8}$ cells l $^{-1}$ and $6.2 \times 10^{8}$ cells l $^{-1}$ (Fig. 2A).

HNF and ciliate abundances followed similar patterns along the oxygen gradient. Both reached the highest numbers around the interface (respective maximum of $5.3 \times 10^{5}$ cells $\mathrm{l}^{-1}$ and 8.8

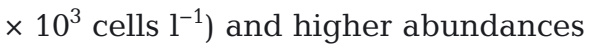
at Landsort Deep than at Gotland Deep (Fig. 2B,D). In contrast to prokaryotes, HNF and ciliate numbers strongly declined with increasing depth and $\mathrm{H}_{2} \mathrm{~S}$ content. Dinoflagellate abundance generally showed the highest abundance in the suboxic zone and declined drastically when $\mathrm{H}_{2} \mathrm{~S}$ appeared in the water column (Fig. 2C). Highest dinoflagellate counts were $\sim 16$ $\times 10^{3}$ cells $^{-1}$ in the oxygen depleted zones of both Gotland Deep in 2007 and Landsort Deep in 2008.

\section{Ciliate distribution and identification}

Beyond the rough classification of protist functional groups, the distinction and enumeration of different ciliate morphotypes allowed us to view the protist zonation at a higher resolution (Fig. 3, Fig. A1 in the Appendix). Although a significant proportion of ciliates remained unidentified at some depths, 3 morphotypes dominated: Metacystis spp., Strombidium spp. and Mesodinium spp., all showing clear shifts in abundance along the oxic-anoxic transition zone (Fig. 3A). Strombidium was present solely in the suboxic zone and disappeared with the complete 
depletion of oxygen. Mesodinium was present at low abundance in the suboxic zone and peaked around the interface. Finally, Metacystis peaked at the interface and extended down to depths with high sulfide concentrations (Fig. 3B).

In 2005, a more precise taxonomic identification by means of live observation and silver impregnation allowed the detection of novel ciliate species (Fig. 4A-I), which will be described in a separate paper. The most frequent ciliates belonged to the genus Metacystis, which was represented by at least 5 species, as judged from cell sizes and morphological structures. At least one of them was a new species, related to $M$. elongata but differing by possessing a caudal cilium (Fig. 4A,E,F). FISH hybridisations, conducted with samples from the oxic-anoxic interface in 2007, showed Metacystis cells to be characteristically associated with large, presumably endosymbiotic Eubacteria and covered by numerous small, presumably ectosymbiotic Gammaproteobacteria (Fig. 5).

Two other ciliates were classified as potential novel genera. One was re-

Fig. 4. Novel ciliates from the chemocline at Gotland Deep in May 2005, observed (A) after nitrate silver impregnation and (B-I) in vivo. $(\mathrm{A}, \mathrm{E}, \mathrm{F}) \mathrm{A}$ potential new species belonging to the genus Metacystis (about $100 \mu \mathrm{m}$ in length). (E,F) The genus is easily recognized by the highly ordered arrangement of the cilia/basal bodies, forming quadrangular meshes. (B, C, G,H) New genus related to Placus spp. (about $90 \mu \mathrm{m}$ in length): (B, G,H) surface views and $(\mathrm{C})$ optical section. $(\mathrm{G}, \mathrm{H})$ The cortex structure of the new genus, which resembles that of Placus spp., although the brush (as shown in $B$ ) is different. (D,I) New plagiocampid genus (about $50 \mu \mathrm{m}$ in length): (D) optical section and (I) surface view showing a highly conspicuous cortex composed of cubic alveoli (arrows in D). B brush, C - cilia, CC - basal body of caudal cilium, EP - excretory pore of contractile vacuole, FV - food vacuoles, LD - lipid droplets, MA - macronucleus, OB - oral basket, OC - oral ciliature, OF - oral flaps. Scale bars $=(F, G) 5 \mu \mathrm{m},(\mathrm{H}) 10 \mu \mathrm{m},(\mathrm{D}, \mathrm{I})$ $25 \mu \mathrm{m},(\mathrm{A}-\mathrm{C}, \mathrm{E}) 50 \mu \mathrm{m}$
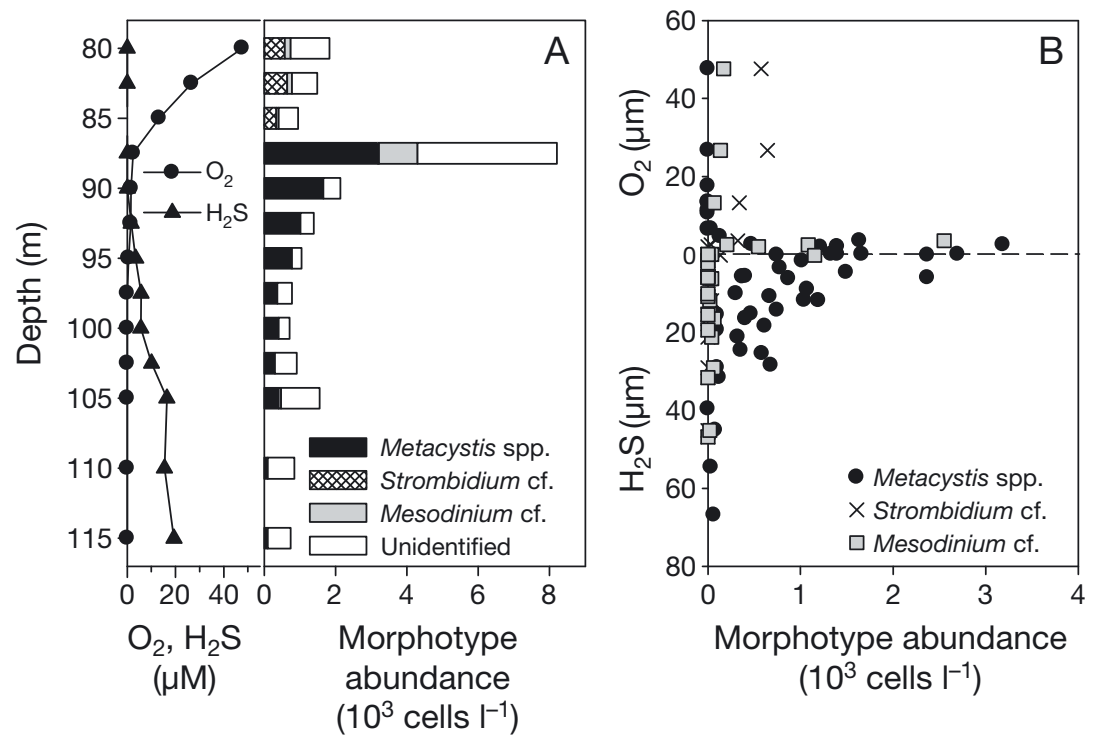

Fig. 3. (A) Changes with depth at the redoxcline in oxygen and hydrogen sulfide concentrations and the relative abundance of the different ciliate morphotypes identified, taken in Landsort Deep in August 2008. (B) Changes in the abundance of the 3 principal ciliate morphotypes distinguished along the redox gradient. Data were pooled for all study sites and sampling years (Gotland Deep in July 2007, August 2008 and Landsort Deep in August 2008). The $y$ axis is split into oxygen and hydrogen sulfide concentration values, with a value of 0 indicating that both were below detection (detection limits: $2 \mu \mathrm{M}$ and $0.2 \mu \mathrm{M}$, respectively)

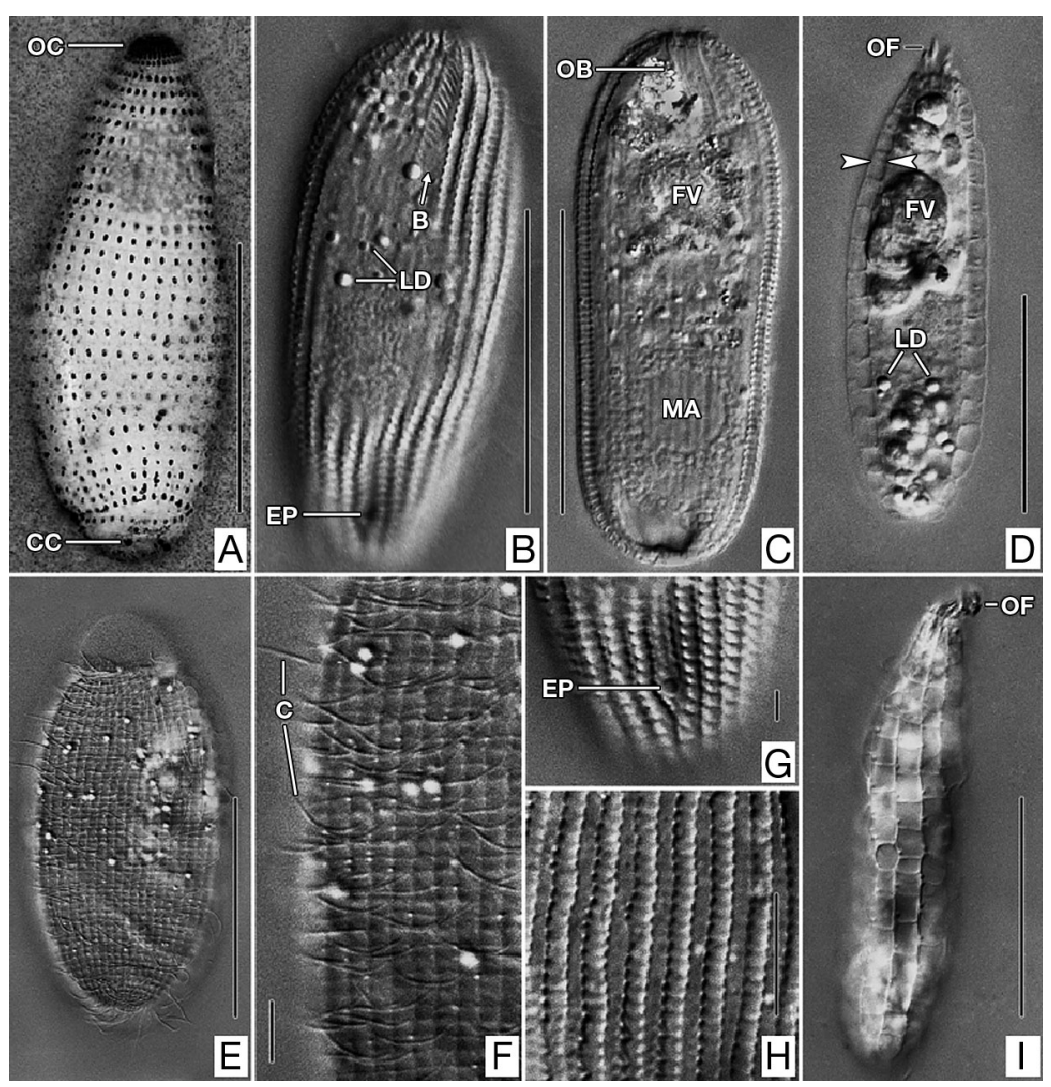



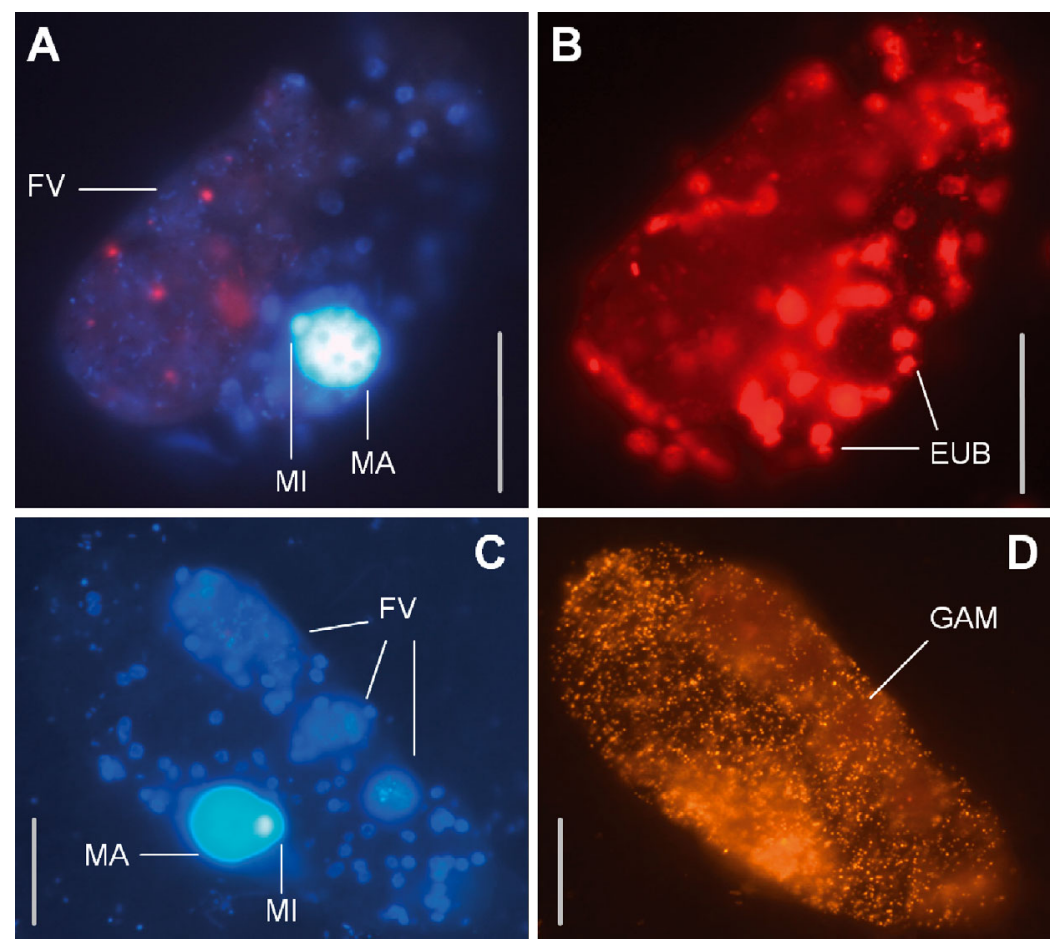

Fig. 5. Epifluorescence micrographs of Metacystis spp. with potentially symbiotic bacteria. (A,C) DAPI-stained Metacystis cells with bacteria in the cytoplasm (note that bacteria on the cell surface are not in focus in C). (B) Fluorescence in situ hybridization (FISH) signal of Eubacteria (EUB338I-III) within the cytoplasm. (D) FISH signal of Gammaproteobacteria (GAM42a) on the cell surface. FV - food vacuole, MI - micronucleus, MA - macronucleus, EUB Eubacteria, GAM - Gammaproteobacteria. Scale bars $=20 \mu \mathrm{m}$

lated to Placus, having a similar cortex structure but differing in the structure of the brush (Fig. 4B,C,G,H). The other belonged to the family Plagiocampidae, as indicated by the characteristic finger-like oral flaps on the dorsal mouth margin but differs from the known genera of this family by the unusual cortex consisting of large, quadrangular alveoli (Fig. 4D,I).
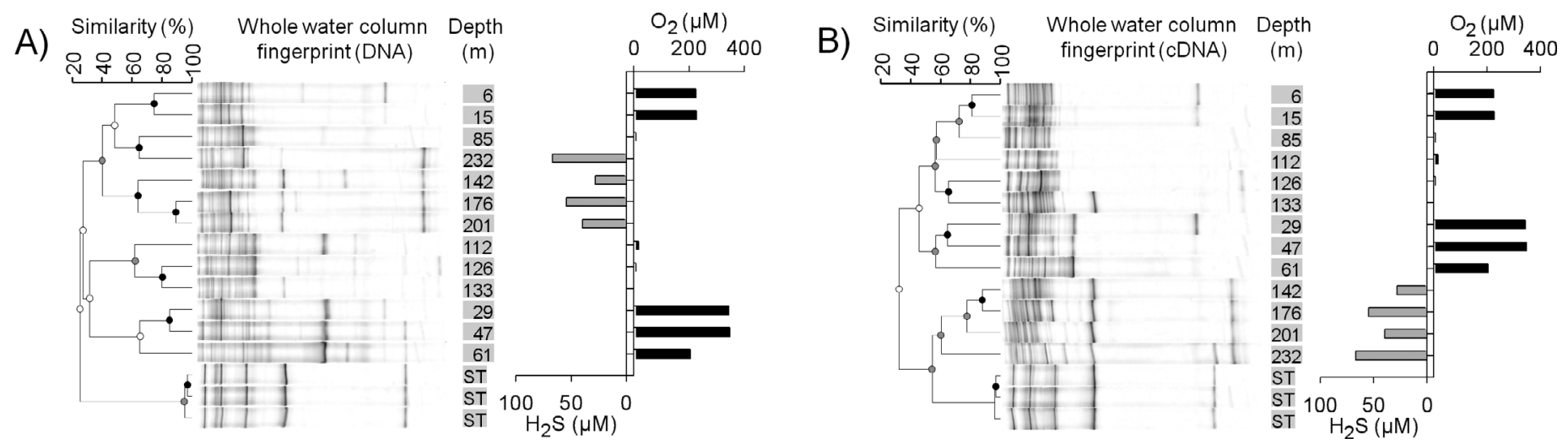

Fig. 6. Dendrograms of (A) DNA-based and (B) cDNA-based DGGE fingerprints of sampled depths in the whole water column of the Gotland Deep in July 2007. Black, grey and white circles at the nodes represent cophenetic correlation coefficients of $100, \geq 85$ and $\geq 70$, respectively. The $\mathrm{O}_{2}$ and $\mathrm{H}_{2} \mathrm{~S}$ values for all depths are given in the bar charts. ST indicates standard lanes 

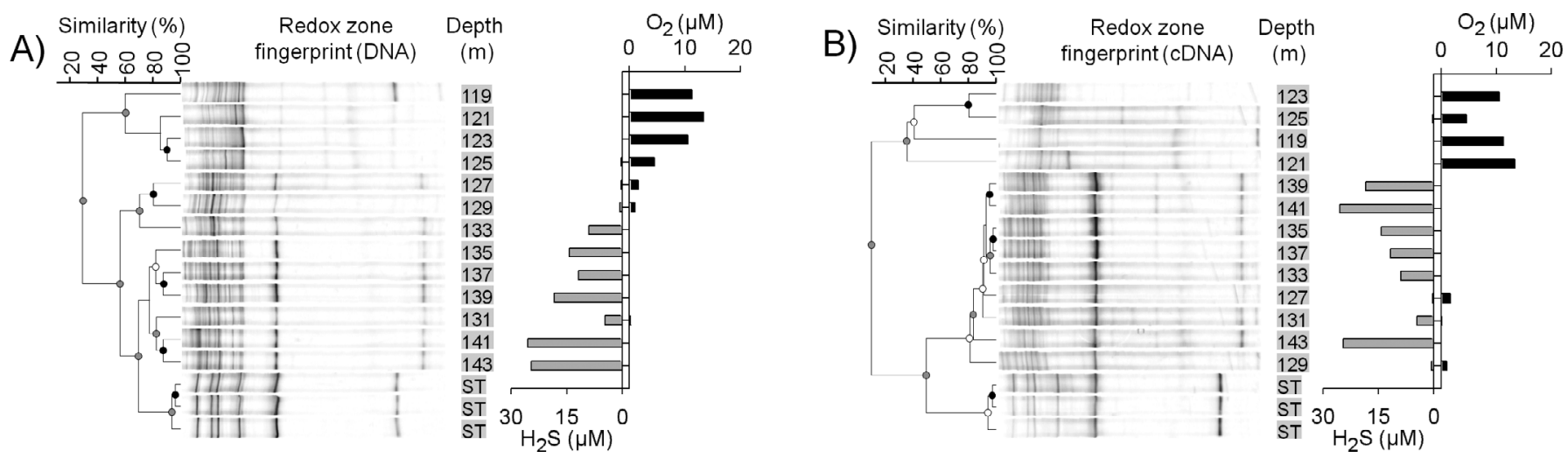

Fig. 7. Dendrograms of (A) DNA-based and (B) cDNA-based DGGE fingerprints of sampled depths in the high resolution redox zone profile of the Gotland Deep in July 2007. Black, grey and white circles at the nodes represent cophenetic correlation coefficients of $100, \geq 85$ and $\geq 70$, respectively. The $\mathrm{O}_{2}$ and $\mathrm{H}_{2} \mathrm{~S}$ values for all depths are given in the bar charts. ST indicates standard lanes

Dendrograms of the high resolution redoxcline profiles showed a clear separation of samples from the suboxic and the sulfidic zone (Fig. 7). Samples from the oxic-anoxic interface (127 and $129 \mathrm{~m})$ were generally more similar to fully sulfidic samples than to suboxic samples, indicating oxygen values around the detection limit of the method applied (1 to $2 \mu \mathrm{M} \mathrm{O}_{2}$ ) to be the demarcation between an oxic and anoxic protistan community (Fig. 7). A clear separation of communities deriving from oxic and anoxic water masses could additionally be confirmed by dendrograms, which were generated solely through the presence and absence of DGGE bands (Jaccard index) for both profiles and through DNA and RNA gels (data not shown).

\section{Phylogenetic identification of protists based on 18S rRNA sequences}

Reamplification of excised gel bands from the 2 DNA- and RNA-based DGGE fingerprints resulted in 38 sequences belonging to microbial eukaryotes. These clustered into 12 OTUs (here also defined as DGGE band positions) within the following taxonomic groups: dinoflagellates (4 OTUs), ciliophorans (2 OTUs), euglenozoans (2 OTUs), jakobids (2 OTUs) and choanozoans (2 OTUs). Most OTUs showed a specific distribution pattern with respect to the redox conditions in the whole water column (Fig. 8B) and the redoxcline profile (Fig. $8 \mathrm{C}$ ).

The euglenozoan phylotype (OTU 10) with $100 \%$ sequence identity to Eutreptiella gymnastica was found solely in surface water samples (based on DNA and RNA gels). Two dinoflagellate phylotypes (OTU 2 based on DNA, OTU 3 based on DNA and RNA) were detected in the cold intermediate and highly oxygenated water layer as well as in the suboxic zone and reached higher relative amplicon abundances in the latter. OTU 3 was closely affiliated (98\% similarity) to the mixotrophic dinoflagellate Karlodinium micrum (not shown in tree), while OTU 2 was very distantly related to any cultured species and formed a long branch with clones from oxic and suboxic marine sites.

In the suboxic zone, the most dominant bands belonged to OTU 5 (10 to $20 \%$ relative intensity in RNA gels), which was closely affiliated to the ciliate Strombidium basimorphum (99\% similarity), and to OTU 1 (up to $44 \%$ in DNA gels), which had $99 \%$ sequence similarity to the pigmented dinoflagellate Gymnodinium catenatum. The latter phylotype was additionally present with lower signal intensity ( $13 \%$ in DNA gel) in sulfidic depths, whereas at the RNA level it was detected only in well oxygenated depths (ca. $3 \%$ relative band intensity in RNA gels).

Throughout the whole sulfidic part of the water column, both RNA- and DNA-based approaches revealed 2 phylotypes with high amplicon abundance. One (OTU 7) accounted for up to 40 and $25 \%$ of relative band intensity in RNA and DNA gels and was affiliated within the excavate jakobids, very distantly related $(82 \%)$ to the closest cultured representative Jakoba incarcerata. The other phylotype (OTU 9) was represented in RNA and DNA gels with up to 20 and $25 \%$ of relative band intensity, branched off within the Symbiontida and was very divergent to cultured species like Calkinsia aureus and Bihospites bacati ( $80 \%$ and $78 \%$ similarity, respectively). Both the jakobid and symbiontid phylotypes were exclusively related to environmental sequences from various anoxic and sulfidic sites (Edgcomb et al. 2002, 


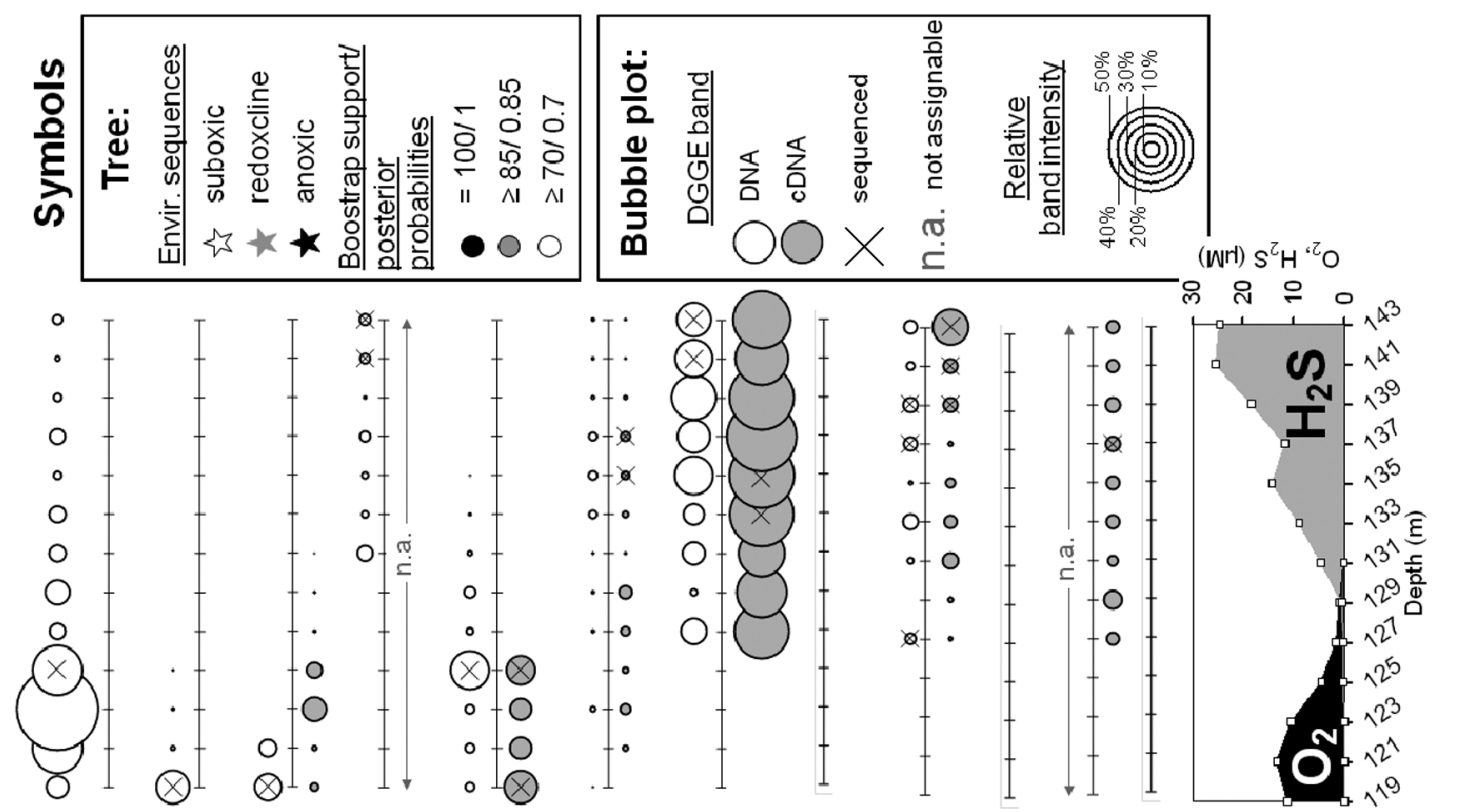

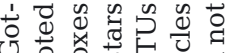

0 ज व $\begin{aligned} & 3 \\ & 0\end{aligned}$

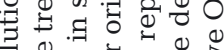

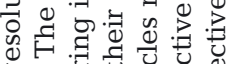

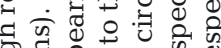

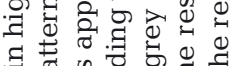
舟

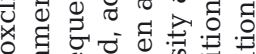

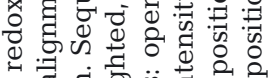

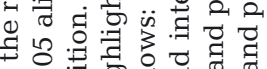
논

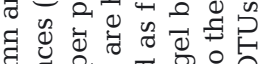
引 बै

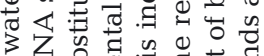

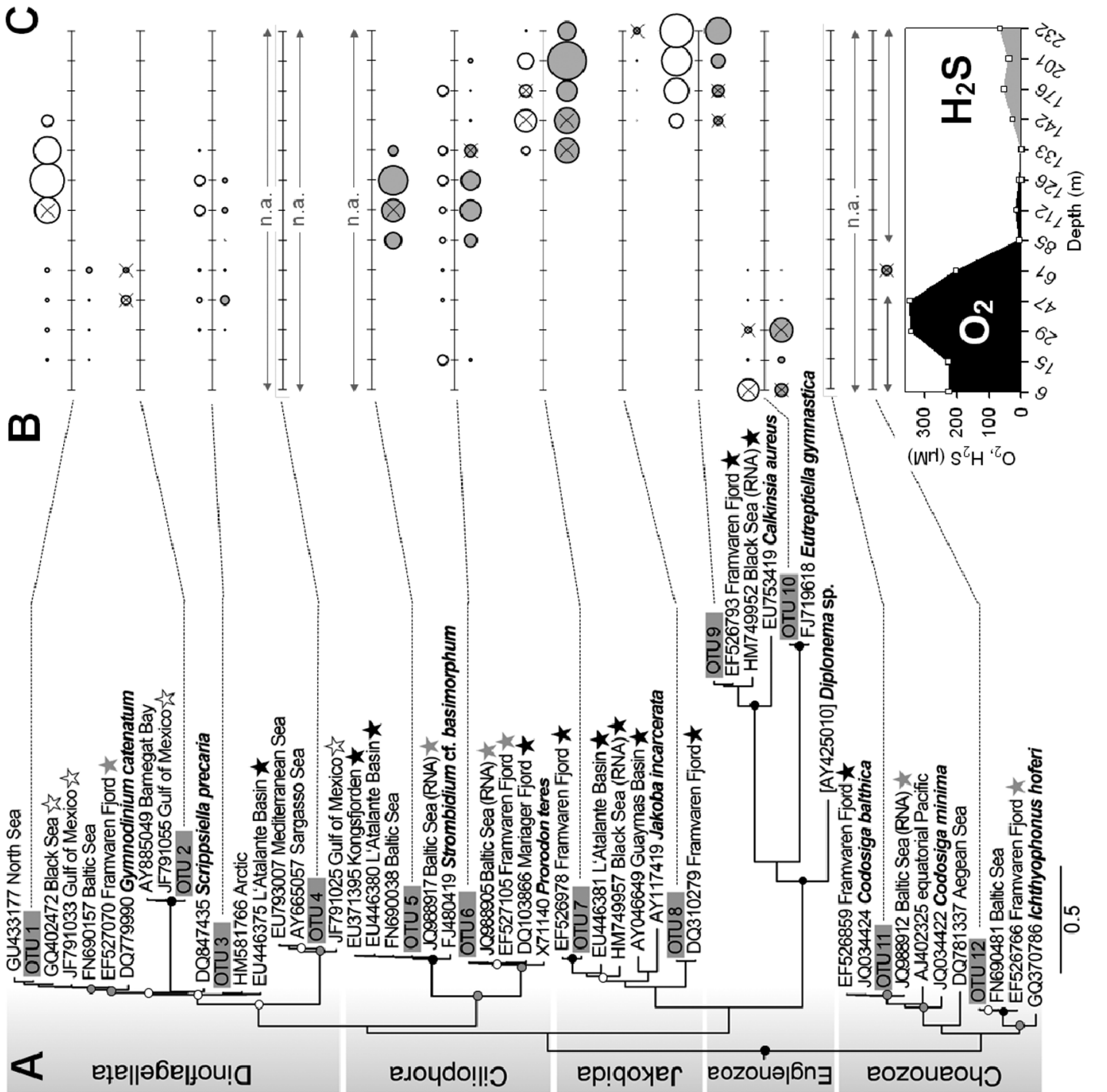

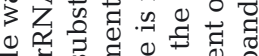

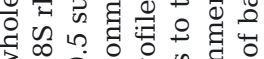
उन 0 .

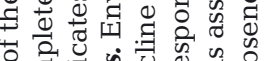
명

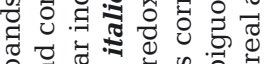

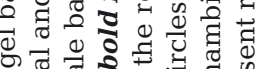

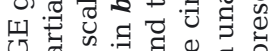
O

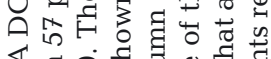

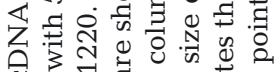

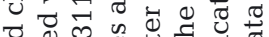
ฮี प्य

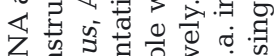

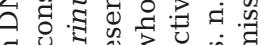
घี ญ ี

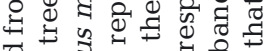

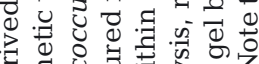
व

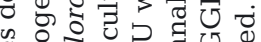

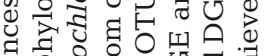
वृ. 원 0 च

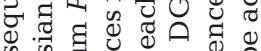
के 要

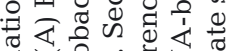

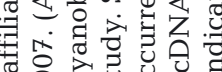

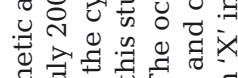

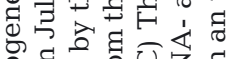

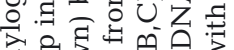

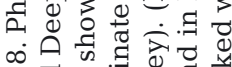
$\infty$ 의 
Alexander et al. 2009, Behnke et al. 2010, Wylezich \& Jürgens 2011) (Fig. 8A). Other phylotypes, which were distributed with lower signal intensity (5 to $10 \%$ ) in the sulfidic zone, belonged to dinoflagellates (OTU 4, only in DNA gel) and choanoflagellates (OTU 11, only in RNA gel). The dinoflagellate phylotype OTU 4 clustered together with environmental syndiniales group 1 sequences from oxic and hypoxic marine systems. The choanoflagellate phylotype (OTU 11) showed $100 \%$ sequence similarity to Codosiga balthica. Another jakobid (OTU 8), barely affiliated $(82 \%)$ to described species but closely affiliated $(100 \%)$ with a clone from the sulfidic boundary in the Framvaren Fjord, was detected solely in the RNA gel from a sample close to the seafloor (232 m) (Fig. 8B). The ciliate phylotype (OTU 6), closely related to Prorodon teres $(98 \%)$, showed a wide distribution from surface waters to the sulfidic zone, with the highest signal intensity of RNA derived bands (up to $15 \%$ ) in suboxic to slightly sulfidic water layers (Fig. 8B,C). The closest environmental sequences were obtained in DNA- and RNA-based studies from other interface and anoxic samples (Fig. 8A).

\section{DISCUSSION}

\section{Protistan community structure along the pelagic redox gradient}

Aquatic systems with anoxic deep water generally have a bimodal vertical distribution of prokaryotic and eukaryotic microbial cells. The peak in cell numbers at the oxic-anoxic interface can exceed the one formed at the surface waters, e.g. in the Cariaco Basin (Taylor et al. 2001, Lin et al. 2007) or vice versa like in the Baltic Sea (Setälä 1991, Detmer et al. 1993, Anderson et al. 2012). The latter was also the case for the deep basins of the central Baltic Sea (Fig. 1), which showed a main change in protist composition; whereas heterotrophic flagellates constituted up to $85 \%$ of the total protistan biomass at the surface, ciliates accounted for a similar percentage at the oxicanoxic boundary (Fig. 1). This represents a fundamental change of the microbial food web structure, with flagellates as the dominant bacterial consumers in surface waters and ciliates as the major bacterivores within the redox zone (Anderson et al. 2012). The high abundance of prokaryotes seems to support the growth of larger ciliate taxa, since ciliates at interface depth were represented by only $20 \%$ of cell counts but with approximately three-quarters of biomass compared to respective surface layer values.
Besides ciliates, dinoflagellates represented a major component in terms of cellular abundance and biomass (up to $56 \%$ of total protistan biomass) in suboxic waters. Sulfidic waters, on the other hand, were characterized by low protist numbers and relatively high prokaryote abundance, which is consistent with observations from other anoxic systems (Fenchel et al. 1990, Massana \& Pedrós-Alió 1994) and previous estimates of low bacterial grazing losses in sulfidic waters of the central Baltic Sea (Anderson et al. 2012).

The 18S rRNA gene and transcript-based analysis also documented the stratification of the protistan communities along the redox gradient (Figs. 6 to 8). The most pronounced shift was observed at oxygen concentrations of 2 to $5 \mu \mathrm{M}$ (ca. 1 to $2 \%$ atmospheric saturation), providing evidence for a turning point of an aerobic to a facultative or obligate anaerobic metabolism (Fig. 7). Indeed, these oxygen concentrations represent the tolerance level of many obligate anaerobes (Fenchel \& Finlay 2008). It is additionally the upper limit where enough reducing power can be supplied for oxygen consumption, effectively acting as an oxygen detoxification mechanism for anaerobic protists (Fenchel \& Finlay 1995), and where endosymbiotic methanogens are active and chemosensory phobic response to $\mathrm{O}_{2}$ is provoked (Fenchel \& Finlay 1990b). Aside from redox conditions as the main driving force, other factors such as prey composition and availability might play an additional role in vertical protist zonation. Altogether, 3 different zones (suboxic, oxic-anoxic interface and sulfidic zone) could be distinguished by their protistan assemblages based on DGGE cluster analysis (Fig. 7 A), phylotype (Fig. 8) and morphotype composition (Figs. 2 \& 3), confirming previous investigations in this system (Anderson et al. 2012).

\section{Dominant protists in suboxic, interface and sulfidic depths}

The suboxic zone appeared to be primarily dominated by dinoflagellates and ciliates of the genus Strombidium. Among the 3 dinoflagellate phylotypes, 2 belonged to the order Gymnodiniales (OTU $1,3)$, whereas one was rather of unknown taxonomic affinity (OTU 2). However, all 3 phylotypes were closely related to many environmental sequences retrieved under similar redox conditions from, e.g., the Black Sea and the Gulf of Mexico (Fig. 7A). However, the parallel 18S rRNA transcript-based approach showed a pronounced discrepancy in phylotype distribution for OTU 1 and 2 raising doubts on their activity in the suboxic zone (Fig. 8). A remark- 
ably similar result was obtained with an identical phylotype to our OTU 1 in the Black Sea (Coolen \& Shtereva 2009). A mismatch between taxon presence (DNA approach) and activity (RNA approach) seems to be a common phenomenon among certain dinoflagellate representatives in oxygen depleted and anoxic environments (Stoeck et al. 2007, Coolen \& Shtereva 2009). It might be that diploid states in their life cycle and the extreme variability of rRNA gene copy numbers (from 65 to 12000 copies cell ${ }^{-1}$ ) in dinoflagellates could cause considerable overestimations of their relative amplicon abundance (Galluzzi et al. 2004, 2010, Zhu et al. 2005). Nevertheless, various dinoflagellate taxa were detected (via RNA) to be preferentially active in the suboxic zone of the Black Sea (Wylezich \& Jürgens 2011) and catalyzed reporter deposition-fluorescence in situ hybridization (CARD-FISH) analysis confirmed that they are active grazers in Baltic Sea suboxic depths (Anderson et al. 2012). These facts, and the distinct abundance peak formed by intact dinoflagellate cells in Baltic Sea suboxic zones, as observed via microscopy, point to an important role of dinoflagellates in this zone (Anderson et al. 2012, this study).

Within the ciliate genus Strombidium, remarkably similar results were obtained by microscopy and $18 \mathrm{~S}$ rRNA-DGGE, indicating a high abundance and activity in the suboxic zone. The strong DGGE band of OTU 5 (Fig. 8), related to Strombidium cf. basimorphum, suggest that the bulk of Strombidium spp. cell counts were comprised by this phylotype. Strombidium species are common photosynthesizers in surface waters, but they are also known mixotrophs and can be frequently detected in oxygen deficient systems (Fenchel et al. 1990, Stoeck \& Epstein 2003, Behnke et al. 2006) where they have been shown to be active grazers (Anderson et al. 2012).

The majority of all ciliate morphotypes detected at the oxic-anoxic interface and the upper sulfidic zone belonged to the genus Metacystis, which was represented by at least 5 species, as determined by the microscopic inspections. At least one represents a novel species with features different to those found in the 14 Metacystis species described so far from marine, brackish and freshwater environments (summarized in Arregui et al. 2010). Metacystis species were often described as sessile or as benthic dwellers (AladroLubel \& Martinez-Murillo 1999, Azovsky \& Mazei 2003, Prast et al. 2007, Arregui et al. 2010). Aside from the findings in a shallow lake (Guhl et al. 1996) and in nutrient-rich brackish tide pools (Dietz 1964, W. Foissner unpubl.), the Baltic Sea seems to be the only aquatic system where Metacystis species are an important component of the pelagic protist community. A high proportion of Metacystis spp. were large forms (70 to $100 \mu \mathrm{m}$ ), which dominated the protistan assemblage with up to $80 \%$ of total biomass in the redoxcline. Since protistan grazing in these strata can eliminate up to $100 \%$ of the prokaryal standing stocks per day (Anderson et al. 2012), Metacystis species are likely the dominant grazers of prokaryotes. In addition, these ciliates seem to maintain partnerships with large numbers of endo- and ectosymbiotic bacteria (Fig. 5), which argues for multiple functions mediated by this key component of the Baltic Sea redoxclines. However, to date, the phylogenetic identity of the genus Metacystis still remains unsolved, since 18S rRNA sequences of all morphologically described Metacystis species are missing.

Other ciliates consistently present at interface depths were Mesodinium spp. as revealed by the morphological approach. Unfortunately, none of those were detected via DGGE, because the employed primer set does not amplify this genus. Mesodinium species have long been recognized as photosynthetically active but are also capable of bacterivory (Myung et al. 2006). Mesodinium rubrum has been shown to form abundance maxima at shallow redoxclines (12 to $14 \mathrm{~m}$ ) of a Baltic Sea inlet in order to exploit high nutrient concentrations before moving back to the euphotic zone (Lindholm \& Mörk 1990). However, the fact that the central Baltic Sea's redoxclines are situated between 90 and $130 \mathrm{~m}$ of depth, motility costs make such a migration behavior less likely. Several molecular surveys conducted in the Mariager and Framvaren Fjords, hypersaline deep sea basins and the Black Sea revealed Mesodinium-related sequences to be frequent at the redoxcline and in anoxic waters, with the deepest RNA signature de. tected at a depth of $3500 \mathrm{~m}$ (Behnke et al. 2006, 2010, Zuendorf et al. 2006, Alexander et al. 2009, Wylezich \& Jürgens 2011). Although, the Mesodinium species present at deep pelagic redoxclines seem to be pigmented (Anderson et al. 2012), they might represent different taxa to the ones present at mixed layer depths or subpopulations of these, which are able to prosper independent of light energy.

The most prominent flagellate phylotypes which emerged in the sulfidic zone, with strong DNA- and RNA-derived signatures in DGGE gels, were affiliated within jakobids (OTU 7) and euglenozoans (OTU 9). The closest relatives of both have been recorded from various anoxic sites such as the Framvaren Fjord (Behnke et al. 2006) or the Black Sea (Wylezich \& Jürgens 2011), and jakobid sequences accounted for almost three-quarters of all clones in a 
genetic library from an anoxic sample of the Baltic Sea (Stock et al. 2009). With our high resolution sampling in Gotland Deep, we demonstrate that these 2 phylotypes are important components of the protist community in the entire sulfidic zone (ca. $100 \mathrm{~m}$ thickness) in terms of presence and activity. The euglenozoan phylotype belonged to the Symbiontida subgroup, which has been recently shown to harbor numerous sulfur or sulfide-oxidizing Epsilonproteobacteria as symbionts (Edgcomb et al. 2011d).

The choanoflagellate phylotype (OTU 11), which was found at the interface and upper sulfidic zone, was very closely related to Codosiga balthica, a recently described isolate from the Baltic Sea oxicanoxic interface. It harbours endosymbiotic bacteria and possess atypical mitochondrial cristae, assumingly as an adaption to oxygen limited and anoxic conditions (Wylezich et al. 2012). Sequences of this taxon were also found in the sulfidic depths of the Gotland Deep in 2005 (Stock et al. 2009), and at the oxic-anoxic interface of Landsort Deep in 2011 (Anderson et al. 2013), indicating that it could be a permanent member and important bacterivore in Baltic Sea hypoxia.

Finally, the dinoflagellate OTU 4 belonged to prominent residents of oxygen deficient and anoxic ecosystems, the syndiniales group 1 (Guillou et al. 2008). Syndiniales comprise a widespread group of obligate parasites with a broad host spectrum ranging from protists to metazoans. Since metazoans generally do not prosper under sulfidic conditions, it is likely that our OTU is a parasite of other anaerobic protists. Further, unlike the assumption that syndiniales are exclusively marine (Guillou et al. 2008), our data suggest this group has a wider salinity tolerance, including at least brackish water conditions.

Currently, for the dominant protists that prosper in distinct redox zones of the Baltic Sea, rather vague ecological functions can be inferred from our findings and the comparative literature. Therefore, comprehensive studies are needed that target these particular taxa and assess their grazing impact, food preferences and symbiotic interactions in order to increase our understanding of the biogeochemical processes of this and other redoxcline systems.

\section{CONCLUSIONS}

The application of morphological and molecular techniques in concert has been frequently recommended as a valuable task for better understanding the structuring and composition of protist communities (e.g. Zuendorf et al. 2006, Behnke et al. 2010, Caron et al. 2012) Following this strategy to examine the dominant protist taxa along pelagic redox gradients of the central Baltic Sea turned out to compensate for shortcomings related to the application of just a single method. The semi-quantitative nature of molecular techniques caused by PCR bias and species specific variations in 18S rRNA gene copy number (Caron 2009) was outbalanced by obtaining cell counts and biomass estimates of certain functional and taxonomic protist groups. Furthermore, microscopy was superior in the detection of larger ciliates like Metacystis and Mesodinium as major components of the redoxcline protist community which remained undetected by the molecular approach. On the other hand, the use of 18S rRNA sequences allowed a more accurate and unambiguous taxonomic identification for some protists. This is especially important for amorphous protists with few diagnostic features (Caron 2009). Like the findings of Savin et al. (2004), the overall congruence of taxa detected by both approaches was unexpectedly low and highlights again the need for such combined approaches to cover a larger portion of protistan assemblages.

The sampling campaigns in different years revealed a remarkably similar morphotype distribution along the redoxclines, which was also highly comparable with the ones observed by Anderson et al. $(2012,2013)$. Additionally, our study shared 3 phylotypes (affiliated within Codosiga, Strombidium and Prorodon) that were detected at similar redox conditions in the Baltic Sea by previous and later sequencing approaches (Wylezich et al. 2012, Anderson et al. 2013). This argues that the Baltic Sea's pelagic redox zones are inhabited by a characteristic and relatively stable community of dominant protist. Observations in the redox gradients of the Framvaren Fjord (Behnke et al. 2010) and the Cariaco Basin (Orsi et al. 2011) provide some evidence for seasonal fluctuations in the protist communities. Further studies in the Baltic Seas pelagic redox zone, with a higher temporal resolution in the yearly cycle, are needed.

Acknowledgements. The study was financed by the Leibniz Institute for Baltic Sea Research Warnemünde and by grants from the German (DFG, JU 367/11-1) and Austrian (FWF, WF P20360-B17) Science Funds. We thank A. Hagenmeier, O. I. Podymov and E. V. Yakushev for chemical field work; A. Grüttmüller for technical assistance with flow-cytometry; S. Busch, R. Hansen, S. Agatha and P. Quintana-Alonso for their help in the identification of protist morphotypes; and G. Jost, M. Labrenz, and C. Wylezich for assistance, comments and advice. We are also very grateful to the captains and crew of the RVs 'Alkor', 'Professor Albrecht Penck' and 'Poseidon' for their brilliant support during the cruises. 


\section{LITERATURE CITED}

Aladro-Lubel MA, Martinez-Murillo ME (1999) First description of the lorica of Metacystis truncata and its occurrence on Thalassia testudinum. J Eukaryot Microbiol 46:311-317

Alexander E, Stock A, Breiner HW, Behnke A, Bunge J, Yakimov MM, Stoeck T (2009) Microbial eukaryotes in the hypersaline anoxic L'Atalante deep-sea basin. Environ Microbiol 11:360-381

Altschul SF, Madden TL, Schäffer AA, Zhang JH, Zhang Z, Miller W, Lipman DJ (1997) Gapped BLAST and PSIBLAST: a new generation of protein database search programs. Nucleic Acids Res 25:3389-3402

Amann RI, Binder BJ, Olson RJ, Chisholm SW, Devereux R, Stahl DA (1990) Combination of 16S rRNA-targeted oligonucleotide probes with flow cytometry for analyzing mixed microbial populations. Appl Environ Microbiol 56: 1919-1925

> Anderson R, Winter C, Jürgens K (2012) Protist grazing and viral lysis as prokaryotic mortality factors at Baltic Sea oxic-anoxic interfaces. Mar Ecol Prog Ser 467: $1-14$

> Anderson R, Wylezich C, Glaubitz S, Labrenz M, Jürgens K (2013) Impact of protist grazing on a key bacterial group for biogeochemical cycling in Baltic Sea pelagic oxic/anoxic interfaces. Environ Microbiol 15:1580-1594

> Arregui L, Pérez-Uz B, Zornoza A, Serrano S (2010) A new species of the genus Metacystis (Ciliophora, Prostomatida, Metacystidae) from a wastewater treatment plant. J Eukaryot Microbiol 57:362-368

Azovsky AI, Mazei YA (2003) A conspectus of the Black Sea fauna of benthic ciliates. Protistology 3:72-91

Behnke A, Bunge J, Barger K, Breiner H, Alla V, Stoeck T (2006) Microeukaryote community patterns along an $\mathrm{O}_{2} / \mathrm{H}_{2} \mathrm{~S}$ gradient in a supersulfidic anoxic fjord (Framvaren, Norway). Appl Environ Microbiol 72:3626-3636

> Behnke A, Barger KJ, Bunge J, Stoeck T (2010) Spatiotemporal variations in protistan communities along an $\mathrm{O}_{2} / \mathrm{H}_{2} \mathrm{~S}$ gradient in the anoxic Framvaren Fjord (Norway). FEMS Microbiol Ecol 72:89-102

Bernhard JM, Buck KR, Farmer MA, Bowser SS (2000) The Santa Barbara Basin is a symbiosis oasis. Nature 403: 77-80

Børsheim KY, Bratbak G (1987) Cell-volume to cell carbon conversion factors for a bacterivorous Monas sp. enriched from seawater. Mar Ecol Prog Ser 36:171-175

> Caron DA (2009) New accomplishments and approaches for assessing protistan diversity and ecology in natural ecosystems. BioScience 59:287-299

> Caron DA, Countway PD, Jones AC, Kim DY, Schnetzer A (2012) Marine protistan diversity. Annu Rev Mar Sci 4: 467-493

Coolen MJL, Shtereva G (2009) Vertical distribution of metabolically active eukaryotes in the water column and sediments of the Black Sea. FEMS Microbiol Ecol 70: 525-539

> Daims H, Brühl A, Amann R, Schleifer KH, Wagner M (1999) The domain-specific probe EUB338 is insufficient for the detection of all Bacteria: development and evaluation of a more comprehensive probe set. Syst Appl Microbiol 22: 434-444

> Dawson SC, Pace NR (2002) Novel kingdom-level eukaryotic diversity in anoxic environments. Proc Natl Acad Sci USA 99:8324-8329
Detmer AE, Giesenhagen HC, Trenkel VM, Auf dem Venne H, Jochem FJ (1993) Phototrophic and heterotrophic pico- and nanoplankton in anoxic depths of the central Baltic Sea. Mar Ecol Prog Ser 99:197-203

Dietz G (1964) Beitrag zur Kenntnis der Ciliatenfauna einiger Brackwassertümpel (Etangs) der französischen Mittelmeerküste. Vie Milieu 15:47-93

Edgcomb VP, Kysela DT, Teske A, de Vera Gomez A, Sogin ML (2002) Benthic eukaryotic diversity in the Guaymas Basin hydrothermal vent environment. Proc Natl Acad Sci USA 99:7658-7662

- Edgcomb V, Orsi W, Bunge J, Jeon S and others (2011a) Protistan microbial observatory in the Cariaco Basin, Caribbean. I. Pyrosequencing vs Sanger insights into species richness. ISME J 5:1344-1356

Edgcomb VP, Orsi W, Breiner H-W, Stock A, Filker S, Yakimov MM, Stoeck T (2011b) Novel active kinetoplastids associated with hypersaline anoxic basins in the Eastern Mediterranean deep-sea. Deep-Sea Res I 58:1040-1048

Edgcomb V, Orsi W, Taylor GT, Vdacny P, Taylor C, Suarez P, Epstein S (2011c) Accessing marine protists from the anoxic Cariaco Basin. ISME J 5:1237-1241

> Edgcomb VP, Breglia SA, Yubuki N, Beaudoin D, Patterson DJ, Leander BS, Bernhard JM (2011d) Identity of epibiotic bacteria on symbiontid euglenozoans in $\mathrm{O}_{2}$-depleted marine sediments: evidence for symbiont and host coevolution. ISME J 5:231-243

> Fenchel T, Finlay BJ (1990a) Anaerobic free-living protozoa: growth efficiencies and the structure of anaerobic communities. FEMS Microbiol Ecol 74:269-276

> Fenchel T, Finlay BJ (1990b) Oxygen toxicity, respiration and behavioural responses to oxygen in free-living anaerobic ciliates. J Gen Microbiol 136:1953-1959

Fenchel T, Finlay BJ (1995) Ecology and evolution in anoxic worlds. Oxford University Press, New York, NY

Fenchel T, Finlay BJ (2008) Oxygen and the spatial structure of microbial communities. Biol Rev Camb Philos Soc 83: 553-569

Fenchel T, Kristensen LD, Rasmussen L (1990) Water column anoxia: vertical zonation of planktonic protozoa. Mar Ecol Prog Ser 62:1-10

Finlay BJ, Esteban GF (1998) Planktonic ciliate species diversity as an integral component of ecosystem function in a freshwater pond. Protist 149:155-165

Foissner W (1991) Basic light and scanning electron microscopic methods for taxonomic studies of ciliated protozoa. Eur J Protistol 27:313-330

Foissner W, Berger H, Schaumburg H (1999) Identification and ecology of limnetic plankton ciliates. Informationsberichte des Bayerischen Landesamtes für Wasserwirtschaft 3:1-793

Galluzzi L, Penna A, Bertozzini E, Vila M, Garcés E, Magnani M (2004) Development of a real-time PCR assay for rapid detection and quantification of Alexandrium minutum (a dinoflagellate). Appl Environ Microbiol 70:1199-1206

> Galluzzi L, Bertozzini E, Penna A, Perini F, Garcés E, Magnani M (2010) Analysis of rRNA gene content in the Mediterranean dinoflagellate Alexandrium catenella and Alexandrium taylori: implications for the quantitative real-time PCR-based monitoring methods. J Appl Phycol 22:1-9

Gasol JM, del Giorgio PA (2000) Using flow cytometry for counting natural planktonic bacteria and understanding the structure of planktonic bacterial communities. Sci Mar 64:197-224 
Grasshoff K, Erhardt M, Kremling K (1983) Methods of seawater analysis, Vol 2. Verlag Chemie, Weinheim

> Grote J, Schott T, Bruckner CG, Glöckner FO and others (2012) Genome and physiology of a model Epsilonproteobacterium responsible for sulfide detoxification in marine oxygen depletion zones. Proc Natl Acad Sci USA 109:506-510

- Guhl BE, Finlay BJ, Schink B (1996) Comparison of ciliate communities in the anoxic hypolimnia of three lakes: general features and the influence of lake characteristics. J Plankton Res 18:335-353

Guillou L, Viprey M, Chambouvet A, Welsh RM and others (2008) Widespread occurrence and genetic diversity of marine parasitoids belonging to Syndiniales (Alveolata). Environ Microbiol 10:3349-3365

Hall TA (1999) BioEdit: a user-friendly biological sequence alignment editor and analysis program for Windows 95/98/NT. Nucleic Acids Symp Ser 41:95-98

> Jost G, Zubkov MV, Yakushev E, Labrenz M, Jürgens K (2008) High abundance and dark CO2 fixation of chemolithoautotrophic prokaryotes in anoxic waters of the Baltic Sea. Limnol Oceanogr 53:14-22

Jürgens K, Massana R (2008) Protistan grazing on marine bacterioplankton. In: Kirchman DL (ed) Microbial ecology of the ocean, 2nd edn. Wiley-Liss, New York, NY, p 383-441

Katoh K, Misawa K, Kuma L, Miyata Y (2002) MAFFT: a novel method for rapid multiple sequence alignment based on fast Fourier transform. Nucleic Acids Res 30: 3059-3066

Kumar S, Skjæveland Å, Orr RJS, Enger P and others (2009) AIR: a batch oriented web program package for construction of supermatrices ready for phylogenomic analyses. BMC Bioinformatics 10:357

> Labrenz M, Jost G, Jürgens K (2007) Distribution of abundant prokaryotic organisms in the water column of the central Baltic Sea with an oxic-anoxic interface. Aquat Microb Ecol 46:177-190

Labrenz M, Sintes E, Toetzke F, Zumsteg A, Herndl GJ, Seidler M, Jürgens K (2010) Relevance of a crenarchaeotal subcluster related to Candidatus Nitrosopumilus maritimus to ammonia oxidation in the suboxic zone of the central Baltic Sea. ISME J 4:1496-1508

Lauterborn R (1901) Die `sapropelische Lebewelt. Zool Anz 24:50-55

> Lin X, Scranton MI, Varela R, Chistoserdov A, Taylor GT (2007) Compositional responses of bacterial communities to redox gradients and grazing in the anoxic Cariaco Basin. Aquat Microb Ecol 47:57-72

> Lindholm T, Mörk AC (1990) Depth maxima of Mesodinium rubrum (Lohmann) Hamburger and Buddenbrock examples from a stratified Baltic Sea inlet. Sarsia 75: 53-64

Manz W, Amann R, Ludwig W, Wagner M, Schleifer KH (1992) Phylogenetic oligodeoxynucleotide probes for the major subclasses of proteobacteria: problems and solutions. Syst Appl Microbiol 15:593-600

> Massana R, Pedrós-Alió C (1994) Role of anaerobic ciliates in planktonic food webs: abundance, feeding, and impact on bacteria in the field. Appl Environ Microbiol 60:1325-1334

Medlin L, Elwood J, Stickel S, Sogin ML (1988) The characterization of enzymatically amplified eukaryotic 16S-like rRNA-coding regions. Gene 71:491-499

Myung G, Yih W, Kim HS, Park JS, Cho BC (2006) Ingestion of bacterial cells by the marine photosynthetic ciliate Myrionecta rubra. Aquat Microb Ecol 44:175-180

- Nye TMW, Liò P, Gilks WR (2006) A novel algorithm and web-based tool for comparing two alternative phylogenetic trees. Bioinformatics 22:117-119

Orsi W, Edgcomb V, Jeon S, Leslin C and others (2011) Protistan microbial observatory in the Cariaco Basin, Caribbean. II. Habitat specialization. ISME J 5:1357-1373

> Orsi W, Charvet S, Vd'ačný P, Bernhard JM, Edgcomb VP (2012a) Prevalence of partnerships between bacteria and ciliates in oxygen-depleted marine water columns. Front Microbiol 3:341

Orsi W, Song YC, Hallam S, Edgcomb V (2012b) Effect of oxygen minimum zone formation on communities of marine protists. ISME J 6:1586-1601

Orsi W, Edgcomb V, Faria J, Foissner W and others (2012c) Class Cariacotrichea, a novel ciliate taxon from the anoxic Cariaco Basin, Venezuela. Int J Syst Evol Microbiol 62:1425-1433

> Pelegri SP, Dolan J, Rassoulzadegan F (1999) Use of high temperature catalytic oxidation (HTCO) to measure carbon content of microorganisms. Aquat Microb Ecol 16: 273-280

Pernthaler J, Glöckner FO, Schönhuber W, Amann R (2001) Fluorescence in situ hybridization (FISH) with rRNA-targeted oligonucleotide probes. In: Paul JH (ed) Marine microbiology. Academic Press, London, p 207-226

> Prast M, Bischoff AA, Waller U, Amann R, Berninger UG (2007) Effect of ciliates on nitrification and nitrifying bacteria in Baltic Sea sediments. Mar Ecol Prog Ser 350: 55-61

Putt M, Stoecker D (1989) An experimentally determined carbon: volume ratio for marine 'oligotrichous' ciliates from estuarine and coastal waters. Limnol Oceanogr 34: 1097-1103

Ronquist F, Teslenko M, van der Mark P, Ayres DL and others (2012) MrBayes 3.2: efficient Bayesian phylogenetic inference and model choice across a large model space. Syst Biol 61:539-542

Savin MC, Martin JL, LeGresley M, Giewat M, RooneyVarga J (2004) Plankton diversity in the Bay of Fundy as measured by morphological and molecular methods. Microb Ecol 48:51-65

Schloss PD, Westcott SL, Ryabin T, Hall JR and others (2009) Introducing Mothur: open-source, platform-independent, community-supported software for describing and comparing microbial communities. Appl Environ Microbiol 75:7537-7541

Setälä O (1991) Ciliates in the anoxic deep water layer of the Baltic. Arch Hydrobiol 122:483-492

Sherr EB, Sherr BF (1993) Preservation and storage of samples for enumeration of heterotrophic protists. In: Kemp P, Sherr BF, Sherr EB, Cole J (eds) Current methods in aquatic microbial ecology. Lewis Publishers, New York, NY, p 207-212

> Sherr EB, Sherr BF (2002) Significance of predation by protists in aquatic microbial food webs. Antonie van Leeuwenhoek 81:293-308

Stamatakis A (2006) RAxML-VI-HPC: maximum likelihoodbased phylogenetic analyses with thousands of taxa and mixed models. Bioinformatics 22:2688-2690

Stock A, Jürgens K, Bunge J, Stoeck T (2009) Protistan diversity in suboxic and anoxic waters of the Gotland Deep (Baltic Sea) as revealed by 18S rRNA clone libraries. Aquat Microb Ecol 55:267-284 
Stoeck T, Epstein S (2003) Novel eukaryotic lineages inferred from small-subunit rRNA analyses of oxygen depleted marine environments. Appl Environ Microbiol 69:2657-2663

Stoeck T, Taylor GT, Epstein SS (2003) Novel eukaryotes from the permanently anoxic Cariaco Basin (Caribbean Sea). Appl Environ Microbiol 69:5656-5663

Stoeck T, Zuendorf A, Breiner HW, Behnke A (2007) A molecular approach to identify active microbes in environmental eukaryote clone libraries. Microb Ecol 53: 328-339

Taylor GT, Iabichella M, Ho TY, Scranton MI, Thunell RC, Muller-Karger F, Varela R (2001) Chemoautotrophy in the redox transition zone of the Cariaco Basin: a significant midwater source of organic carbon production. Limnol Oceanogr 46:148-163

Ulloa O, Canfield DE, DeLong EF, Letelier RM, Stewart FJ (2012) Microbial oceanography of anoxic oxygen minimum zones. Proc Natl Acad Sci USA 109:15996-16003

Utermöhl H (1958) Zur Vervollkommnung der quantitativen Phytoplankton- Methodik. Mitt Int Ver Theor Angew Limnol 9:1-38

- Weber F, del Campo J, Wylezich C, Massana R, Jürgens K (2012) Unveiling trophic functions of uncultured protist taxa by incubation experiments in the brackish Baltic Sea. PLoS ONE 7:e41970

Weinbauer MG, Fritz I, Wenderoth DF, Höfle MG (2002)
Simultaneous extraction from bacterioplankton of total RNA and DNA suitable for quantitative structure and function analyses. Appl Environ Microbiol 68:1082-1087

- Willen T (1962) Studies on the phytoplankton of some lakes connected with or recently isolated from the Baltic. Oikos 13:169-199

> Wright JJ, Konwar KM, Hallam SJ (2012) Microbial ecology of expanding oxygen minimum zones. Nat Rev Microbiol 10:381-394

> Wylezich C, Jürgens K (2011) Protist diversity in suboxic and sulfidic waters of the Black Sea. Environ Microbiol 13: 2939-2956

- Wylezich C, Karpov SA, Mylnikov AP, Anderson R, Jürgens K (2012) Ecologically relevant choanoflagellates collected from hypoxic water masses of the Baltic Sea have untypical mitochondrial cristae. BMC Microbiol 12:271

Zhu F, Massana R, Not F, Marie D, Vaulot D (2005) Mapping of picoeucaryotes in marine ecosystems with quantitative PCR of the 18S rRNA gene. FEMS Microbiol Ecol 52: 79-92

Zubkov MV, Sazhin AF, Flint MV (1992) The microplankton organisms at the oxic- anoxic interface in the pelagial of the Black Sea. FEMS Microbiol Ecol 10:245-250

Zuendorf A, Bunge J, Behnke A, Barger KJA, Stoeck T (2006) Diversity estimates of microeukaryotes below the chemocline of the anoxic Mariager Fjord, Denmark. FEMS Microbiol Ecol 58:476-491

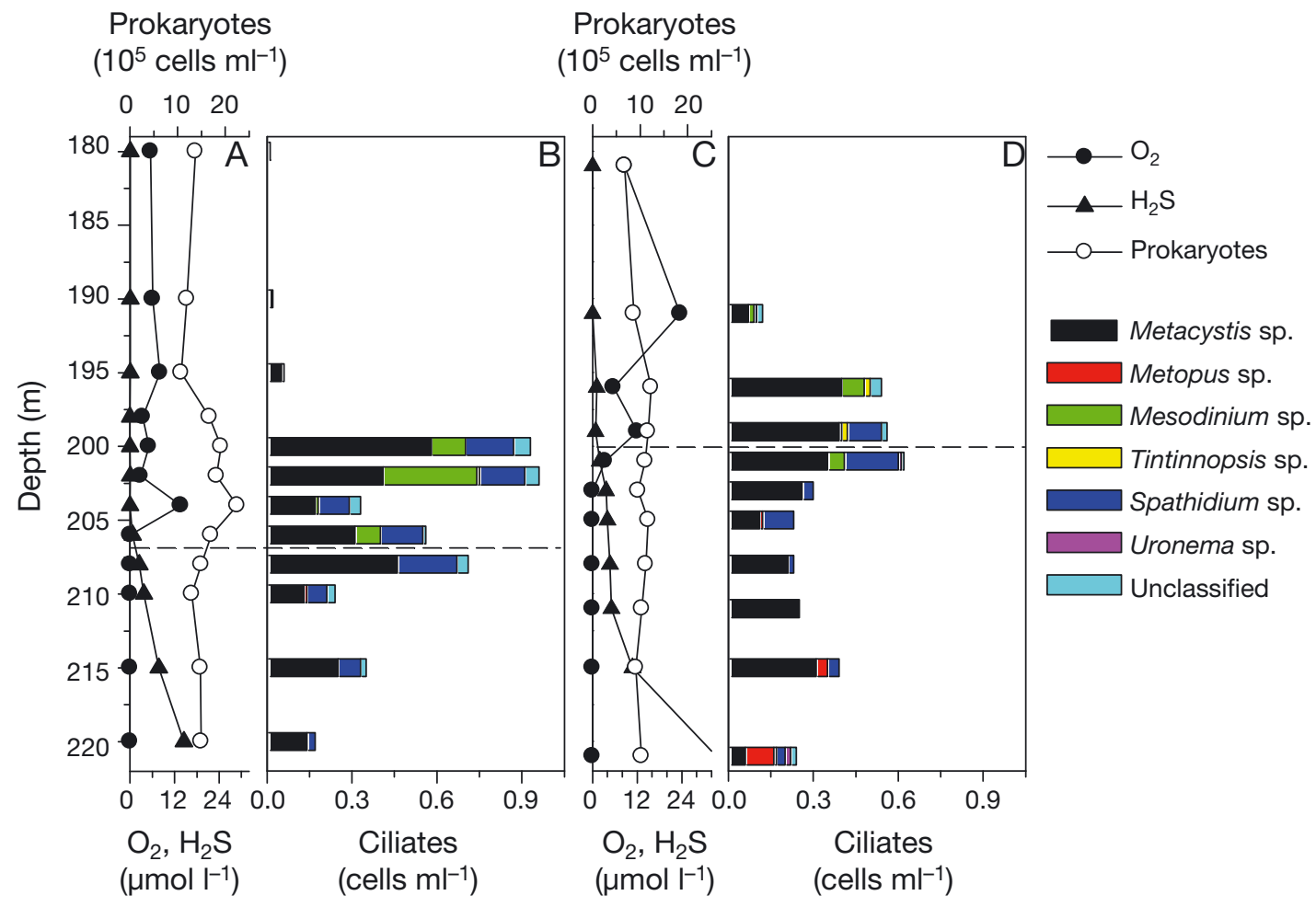

Appendix. Fig. A1. High resolution profile of ciliate morphotype composition during reconstruction process of the redox zone at Gotland Deep on (A,B) 4 May and (C,D) 6 May 2005. Changes with depth in (A,C) oxygen, hydrogen sulphide and prokaryote concentrations and in $(B, D)$ ciliate cell-counts are shown. The horizontal dashed line represents the oxic-anoxic interface 